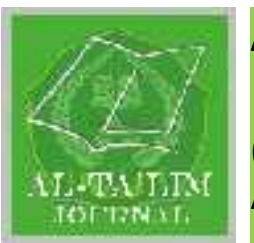

AL-TA'LIM JOURNAL, 23 (2), 2016, (146-155)

(Print ISSN 1410-7546 Online ISSN 2355-7893)

Available online at http://journal.tarbiyahiainib.ac.id/index.php/attalim

\title{
Improving Students' Mastery on Simple Present Tense Through Climbing Grammar Mountain Game
}

Received: $10^{\text {th }}$ December 2015; Revised; $28^{\text {th }}$ February 2016; Accepted: $20^{\text {th }}$ July 2016

Permalink/DOI: http://dx.doi.org/10.15548/jt.v23i2.246

\section{Fadila Taslim}

Sekolah Tinggi Keguruan dan Ilmu Pendidikan Abdi Pendidikan Payakumbuh, West Sumatra, Indonesia Email:Fad_1203@yahoo.co.id

\begin{abstract}
This study aims to determine whether the use of Climbing Grammar Mountain Game gave significant improvement on students in learning simple present tense. Classroom action research was used in this study where the data were analyzed by using quantitative and qualitative approaches. The population of the study was the students of grade eleventh at SMPN 1 Luak 50 Kota. There were 21 students in this class. Six kinds of instruments were used to collect data, namely teaching ,scenario, observation sheet, questionnaire, test, interview, and teacher's journal. This study ran for two cycles. In the second cycle, it was shown that there was gradual improvement from the previous cycle which changed from 64 (insufficient) to 79 (sufficient) of the mean score. it was more than criteria of the students' mean score which were determined in this study and it was significant because it proved that the students enthusiasm to study simple present tense, it mean that the students liked and were not bored again so this was a motivation for them to more concentrate to study simple present tense and they could use it in daily life for communication. They understand that simple present tense is important in learning English because it is used in daily life, either in writing and spoken language. It could be concluded that Climbing Grammar Mountain Game could improve the ability of the students in class VII B of SMPN 1 Luak 50 Kota in using Simple Present Tense.
\end{abstract}

Keywords: Grammar mastery, simple present tense, climbing grammar mountain game

How to Cite: Taslim, F. (2016). Improving the students' mastery on simple present tense through climbing grammar mountain game. Al-Ta Lim Journal, 23(2). doi:http://dx.doi.org/10.15548/jt.v23i2.246

\section{INTRODUCTION}

English has become a foreign language in indonesia. Thus, the government has obligated the english subject as a compulsory one in any kinds of high school in indonesia. English has four skills, namely, reading, listening, speaking and writing and two components such as grammar and vocabulary. These skills and components are taught in every level of high school in Indonesia. Yet, one of the components, grammar, is the most difficult one for the students. Probably it because there are many rules that must be followed by the students. Also, grammar is not taught in the specific times, but it is integrated to the four skills that the students learn in the classroom. 
Based on information obtained from the English teachers at SMP 1 Luak 50 Kota, it was found that many students still had difficulties in mastering grammar, especially in mastering Simple Present Tense. It is one of the basic tenses that should be mastered by the students since it dominatly use in daily life. Besides that, in identifying the text such as the descriptive text or the procedure text, the Simple Present Tense is also used. In the interview, it was found that class VII B was the class which had the lowest ability in using Simple Present Tense especially in using subject-verb agreement, adverb and the usage. Based on the information given by the English teacher, the students of this class had low ability in mastering grammar especially simple present tense when they were in elementary school. They could not use the subject-verb agreement and the usage; it was known that the ability of the students in using Simple Present Tense was low. It was found that many students often did not understand why some sentences used auxiliaries, is, am, and are instead of auxiliaries do and does. Some students still chose "I am study English" instead of saying "I study English'.

Moreover, some students were confused in differentiating which subject used auxiliaries do and which ones used does. All problems above arose since the students did not understand the right rule of Simple Present Tense. Therefore, the researcher was encouraged to find out the causes of the problems undergone by the students through interview. The students' comments were as follows: Simple present tense was still difficult, they felt bored to study grammar, they did not understand what their teacher had taught about simple present tense and they did not get enough practice in using simple present tense. And the most significant reason of this was the way how the teacher taught Simple Present Tense influenced the students' motivation in learning. From the observation, the researcher found that the English teacher tended to teach the grammar deductively. The teacher taught Simple Present Tense by giving a note and giving a pattern on how to develop a sentence for simple present tense on the whiteboard, giving some examples, and then asking the students to take a note. After that the students were only given limited time to do some exercises. Here the students easily felt bored of the teaching methods since there was no interesting and attractive activity involved in their learning process.

Furthermore, the students also often thought that learning Simple Present Tense was difficult. This assumption made the students was afraid and werenot motivated to study. As a result, most of the students were afraid to ask the points that they did not understand to the teacher. This situation made the students passive in their learning process. The students' enthusiasm was much related to the technique used by the teacher in transferring the lesson. The students would become not interested in learning if the technique used was monotonous. It made the learning process not effective. Based on this statement, English teachers should think critically in order to find creative approach in teaching grammar so that the students will take much participation during the learning process. One of the creative approaches in teaching English grammar was games. Saricoban and Metin (2000) stated that through well-planned games, learners can practice and internalize vocabulary, grammar and structure extensively. Play and competition that are provided by games enhance the motivation of the students and reduce their stress. This will help them to acquire certain essential language skills. One game that can be applied in classroom is Climbing Grammar Mountain Game. According to Gunn and McCallum (2005), Climbing Grammar Mountain Game helps improve the students ${ }^{\text {ee }}$ understanding of grammatical usage and helps the students learn from others through peer review, team work, and group discussion. In relation to this, the researcher was interested in 
conducting a study which was focused on improving ability to use Simple Present Tense using mountain game teaching approach to students of grade VII B of SMP 1 Luak 50 Kota. The writer sought how the implementation of Climbing Grammar Mountain Game in improving ability to use simple present tense to the students was and how much Climbing Grammar Mountain Game could improve the ability of grade VII B of SMP 1 Luak 50 Kota to use Simple Present Tense.

\section{Teaching Grammar}

There has been an ongoing argument about teaching grammar in class. Some language educators and language learners assume that it is not vital to teach grammar in language classes separately because it is viewed as such a skill that learners may acquire when they are exposed to the language. Some language researchers also think that for language learners, meaning should be more emphasized than the form and the instructors should teach the language in order to convey meaning and for communication.

On the other hand, most of the language educators and researchers think that all skills of language are in a circle and they should be taught in an order giving equal importance to all as language teaching. Some others think that being competent about the grammatical structures of a specific language is very critical because grammatical competence is acknowledged equal to being fluent in communicative skills. However, there is not a consensus about the effectiveness of grammar teaching.

Indeed, grammar teaching is a must in language classrooms and adopting the most appropriate way to teach in the classroom according to student profile is considered an important issue. It is in line with what Folse (2004) says that the teachers play an important roles in determining how much grammar instruction they need, which grammar points to teach, and what kinds of grammar activities are best for them since no one knows the subject matter and the class situation better than the teachers themselves.

\section{Simple Present Tense}

Simple Present Tense is one of tenses that is important to be mastered by the students. Wrong perception of Simple Present Tense will affect the students' ability in constructing or understanding Simple Present Tense sentences. Simple present tense is tense denoting an action happening in this time. This tense is used to talk about things in general. We are not only thinking about now, but it is used to say something is true in general (Hinkel, 2002).

\section{a. Usage}

The way in which a word or phrase or sentence is normally and correctly used. Here are the rules of usage of simple present tense:

Auxiliary verb + main verb

Do/Does Base exceptions:

There are three important

1. For positive sentences, we do not normally use the auxiliary.

2. For the 3rd person singular (he, she, it), we add -s or -es to the main verb and -es to the auxiliary in the negative and questions form.

3. For the verb to be, we do not use an auxiliary, even for questions and negatives.

\section{b. Meaning}

Simple Present Tense has three important meanings (Leech \& Svartvik, 2013). They are:

1. A present state

a) Simple Present Tense often indicates a state which exists now that refers to a fact which is generally true. For example: The sun rises in the east.

b) Simple Present Tense can also refer to states that can change For example: Where does your uncle work? I'm sorry, I don't know. I 
think he works in a fashion company.

2. A present habit

a) Simple Present Tense refers to an action repeated regularly such as habit or custom.

For examples:

Robby smokes.

Anita plays tennis.

b) Simple Present Tense can be used with frequency adverbs like always, never, sometimes, ever, usually, often, etc.

For example: Billy sometimes goes fishing in the summer.

3. A present event

This meaning of Simple Present Tense is less common. It refers to an event which happens at the very moment of speaking.

For examples:

I regret that I made a mistake.

I beg you to be more careful.

\section{Climbing Grammar Mountain Game}

Gunn and McCallum (2005) introduce new game in teaching Grammar namely Climbing Grammar Mountain Game. Climbing Grammar Mountain Game is an easy game that is prepared and adapted to the unique needs of different classrooms. The game promotes learning opportunity and enthusiasm for the learners. In implementing Climbing Grammar Mountain Game in the classroom process, the teachers will focus on attaining two main objectives (Gunn \& McCallum, 2005; Yolageldili \& Arikan, 2011). They are :

1. To improve students"e understanding of the fundamentals of effective written communication, especially grammatical usage and sentence construction.

2. To help the students learn from others through such activities as peer review, team work, and group discussion.
Here are the steps of the implementation of Climbing Grammar Mountain in the classroom in teaching Simple Present Tense (Gunn \& McCallum, 2005):

1. Draw some vertical climbing lines on the board or on an overhead transparency. The amount of the vertical climbing lines depends on how many teams are in the classroom. Leave space on the bottom of the transparency to show one sentence at a time.

2. Divide each line into 10 segments to represent vertical feet.

3. Prepare a series of sentences. Before starting the game, ask the students to get into teams of four or five people depending on how many students are in the class. Let the students choose a name for their team. And then start by playing a practice, round of the game.

4. Provide the whole class with a correct sentence that is fairly easy to identify as correct. Ask each team how many vertical feet (up to a maximum of 20) they are willing to award to it. And then show how the team will be moved up the mountain by that many vertical feet.

5. Next, provide a sentence that is incorrect. If the students cannot recognize it as incorrect and they award some vertical distance to it, they must go back down the mountain that many feet. If students recognize the sentence as incorrect and do not wager any vertical feet on it, they can stay where they are.

6. After the practice round, begin the actual play by using the sentences prepared. Draw one sentence at a time. Show one sentence to the first team. If the sentence is incorrect, give the playing team the first chance to correct the sentence for 5 bonus feet. If that team cannot correct the sentence, give chance to another group and give the answering team an extra 5 bonus feet. Then, move on to the next team, drawing a new sentence. The game continues until all the sentences have been used. 


\section{METHOD}

The research conducted in the form classroom action research. The data of this study were analyzed by using quantitative and qualitative approaches. The quantitative approach was used to analyze the scores of the data. The qualitative approach was used to describe the characteristic of the data. The population of the study was the students of grade eleventh at SMPN 150 Kota, especially, the students of grade VII B. There were 21 students in this class.

In this study, the researcher used six kinds of instruments to collect data, namely teaching scenario, observation sheet, questionnaire, test, interview, and teacher's journal. The data of this study were analyzed using qualitative and quantitative methods. The qualitative method was used to describe the characteristics of the data, while the quantitative method was used to analyze the scores of the data. After all of the data were collected, the data were analyzed by following steps: first, the main data obtained from the interview and observation were identified and analyzed. Second, the researcher evaluated the results of the test made by the students in using simple present tense and score was given. Third, the researcher found out the students' level of mastery. The last, the researcher found out the students' mean score. The mean score showed the level of improvement achieved by the students after following teaching and learning process through the implementation of Climbing Grammar Mountain Game. The formula can be seen as follows:

1. The score of each student

$$
\begin{aligned}
& X=\frac{N}{T l} \times 100 \% \\
& \text { Notes: } \\
& \mathrm{X}=\text { the score of each student } \\
& \mathrm{N}=\text { the number of correct answer } \\
& \mathrm{n}=\text { the number of the items }
\end{aligned}
$$

In this type of evaluation, the level of mastery was determined by using minimum competency, which was considered the passing score from the all materials that should be acquired, that is, $\geq 7.0$ or $\geq 70 \%$ and fell into sufficient category.

2. The students' level of mastery

$\mathrm{L}=$ The total items answer $\mathrm{x} 100 \%$ Maximum score

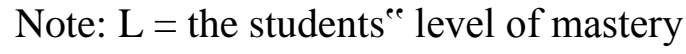

The mean score of the whole students The formula is:

$$
\begin{aligned}
& \bar{X}=\frac{\sum X}{N} \\
& \text { (Masidjo, 1995) } \\
& \text { Notes : } \\
& \mathrm{X}=\text { the students }{ }^{\text {ee }} \text { mean score } \\
& \mathrm{X}=\text { the sum of the score of all students } \\
& \mathrm{N}=\text { the number of students/subjects }
\end{aligned}
$$

The mean score showed the improvement acquired by the students. If the mean score or the percentage items answered correctly was $\geq 7.0$ or $\geq 70 \%$, the cycle would be stopped. The study would be stopped and considered successful if the classical mean score of the students was or more than 7.0 or $70 \%$.

For the qualitative data, it was obtained from the result of the questionnaires. The questionnaires were measured form of percentage by using the following formula:

$y_{0}=\frac{\text { number of subjetcs choosing un item }}{\text { mumber of the subjects }} \times 100 \%$

\section{RESULTS AND DISCUSSION}

As stated in previous chapter, the aim of this study was to improve the ability of the students of grade seven of SMPN 150 Kota in Simple Present Tense by using Climbing Grammar Mountain Game. This study was formulated after conducting the preliminary observation in the teaching learning process, after observing the class activities and teacher's preparation. Then the result was the 
students had some problems in using simple present tense especially in using subject-verb agreement, adverb and usage. In using subject- verb agreement, the students could not differentiate when they used verb added by -s or -es. They added -s or -es in the third plural person, indeed, it did not need added by -s or -es. We use the verb added by -s or -es, if the subject is the third singular person (she, he, it) and if the subject is the first singular person (I), first plural person (we), the second singular and plural person (you), third plural person(they), it is not added by -s or -es. In using adverbial of time, the students could not use the appropriate adverb of frequency to make how often an action took place clear, for example the sentences : Nita....eats fried rice because she hates it (see in the pre test). In this sentence, most of students put the adverb of frequency 'always' instead of 'never'. It indicated that the students did not understand the meaning of adverbial of frequency, thus, the students must find in Indonesian the meaning of adverbial of frequency which was often used.

On one hand, they could put appropriate adverbial of frequency in simple present sentences. In the other hand, the students could not use the appropriate of adverbial of time either starting with 'When?'. For example, 'Those men play tennis...'(see in the pre test). Most of students answered 'tomorrow' instead of 'every Sunday'. They did not know the adverbial of time used in Simple Present Tense and Future Tense. The students did know the pattern of question in Simple Present Tense. For example, 'Do ...like bananas. (See in the pre test). Most of students answered 'Mita' instead of Andra and Tono'. Do is used when the subject is the first person, second person, or third person plural and Does is used when the subject is the third person singular. Based on the result of pre- test, the mark of subjectverb agreement and usage aspects were lower than adverbial aspects. It indicated that students had low ability in using Simple
Present tense. The second problem was feeling bored of following the lesson because of the monotonous teaching and learning process. Those problems were also supported by the result of pre-test in which the main score was 42. It was because of the teacher's technique was less appropriate which made the class became bored and less motivated.

Regarding the problem above, the teachers had important role in helping the students to be able to improve grammar specially Simple Present Tense. In teaching Simple Present Tense to junior high school students, the English teachers were expected to be active, creative and innovative in using different strategies, methods, and techniques. This finding is in line with (Yolageldili \& Arikan, 2011). They mentioned that the use of games was only to make their teaching interesting, challenging, motivating, and at the same time enjoyable, which could create students' participation. Teaching English Grammar especially Simple Present Tense trough game was for good for young learner. Moreover, teaching English using games address these problems;

1. Games make learning fun so the class and children are willing participants and not just there because they have to be.

2. Playing a game has a purpose to it, an outcome, and in order to play students have to say things - they have a reason to communicate rather than just repeat things back mindlessly. Therefore, they want to know and learn more.

3. Games stimulate and motivate children to new levels.

4. Students get to use the language all the time during the games.

5. The games lend themselves perfectly to quick bursts of revision. By using some of the games it can revise a massive amount of vocabulary and grammar in a few minutes.

There are a great number of language games that can be used in teaching learning 
processes. It can offer some choices for the teacher to decide which game can be used and appropriate for their students' level. However, in deciding which game to use in a particular class and which games will be most appropriate and most successful with their students, teacher must take many factors.

Games involve many factors, such as : rules, competition, relaxation, and learning in particular. The main focus using games in class is to help students learn and have fun. It is important that before playing, the rules of the games need to be clearly explained and well understood by students. For examples, demonstrations can also be very helpful because it can help students understand the game and help them follow the rules. It is noteworthy that, in playing games, competition is very important because it can stimulate and encourage students to participate in the activity since naturally they want beat the other teams. One of the interesting and effective games to use was Climbing Grammar Mountain Game. It was one of some games which was appropriate to be used in teaching grammar specially Simple Present Tense because it was an easy game that was prepared and adapted to the unique needs of different classrooms. The game promoted learning opportunity and enthusiasm for the learners. In implementing Climbing Grammar Mountain Game in the classroom process, the teachers focused on attaining two main objectives (Gunn \& McCallum, 2005). They were:

1. Improving students' understanding of the fundamentals of effective written communication, especially grammatical usage and sentence construction.

2. Helping the students learn from others through such activities as peer review, team work, and group discussion.

There were two advantages that could be gained through the use of Climbing Grammar Mountain Game in teaching Simple Present Tense. They were:

1. Its adaptability

The Climbing Grammar Mountain Game was its adaptability. It could be implemented to young learner.
2. It provided sense of satisfaction to the students during their learning grammar process. The sense of satisfaction for the students came from the fact that they could work and climb the mountain together. Like in the real climbing mountain, in this game the students were given sentences that were not too easy for them. It aimed at motivating the students to use all their ability, knowledge and understanding of Simple Present Tense.

After conducting the action through the application of Climbing Grammar Mountain Game in two cycles, the students' ability in Simple Present Tense improved. It can be seen by comparing the students' mean score on the pre-test, post test I and post test II. The students' improvement could also be seen from the students' mean score on each aspect of Simple Present Tense such as Subject-Verb agreement, the use of adverbial time and frequency, and the usage. The following table shows the detailed mean scores of the students in using each aspect of Simple Present Tense.

Table 2. General Mean Score of the Students' Ability in Using Each Aspect of Simple Present tense

\begin{tabular}{llccc}
\hline No & $\begin{array}{l}\text { Aspect of Simple } \\
\text { Present Tense }\end{array}$ & $\begin{array}{c}\text { Pre- } \\
\text { test }\end{array}$ & $\begin{array}{c}\text { Post- } \\
\text { test I }\end{array}$ & $\begin{array}{c}\text { Post- } \\
\text { test II }\end{array}$ \\
\hline 1 & $\begin{array}{l}\text { Subject-Verb } \\
\text { agreement }\end{array}$ & 3,7 & 5,5 & 7,6 \\
2 & $\begin{array}{l}\text { Adverbial of time } \\
\text { and frequency }\end{array}$ & 5,6 & 8,0 & 8,5 \\
3 & $\begin{array}{l}\text { Usage } \\
\text { Mean Score }\end{array}$ & 3,3 & 5,8 & 7,6 \\
& 42 & 64 & 79 \\
\hline
\end{tabular}

The table above shows clearly that there was a gradual improvement of the post tests that had been done. The students' mean score on pre-test that was 42 (poor) gradually improved into 64 (insufficient) in cycle $\mathrm{I}$. Nevertheless, the mean score that the students gained on cycle I had been satisfactory yet and still did not fulfill the standard of passing score. In cycle 1 (First and second Session), the students' ability to use Simple Present Tense especially subject - verb agreement and usage were lower than adverbial. The students were still confused about when verb used -s 
or -es and the verb did not use -s or -es; in other words, they were still confused about the subject, so they felt difficult to match the subject and verb. For example, the sentence 'However, people does not like to buy their daily needs there because the things are expensive (First Session). The students told that this sentence was true indeed the answer was 'do not'. The students did not know that 'people' was the third plural person. In usage, the student did not distinguish the nominal sentence from verbal sentence. For example is in the sentence 'The sellers are put their things in good order'. The student said that it was true; indeed it was not true. The correct sentence was 'The sellers put their things in good order'; indeed this sentence needn't the linking verb 'are'. If it was added by 'are', it would change as passive voice and the verb would also change into verb 3 . In the second session, the aspects as subject - verb agreement and usage were also lower than adverbial. After conducting the implementation of Climbing Grammar Mountain Game in the first session and second session, the researcher gave test as post - test 1 to know how far the ability of students during learning process. The result of post test 1 , the ability of students was still low especially in aspects of subject - verb agreement and usage. For example, in the aspect of subject - verb agreement, in the sentence 'My parents....to go shopping very much, most of students' answer matched the verb 'likes' instead of 'like' because 'the parents' is third plural person.

With regard to the usage, in sentence 'What...your father's job? Most students answered 'does" instead of 'is'. It indicated that the students did not distinguish verb from noun; the word 'job' is noun, so it must be added by linking verb 'is' because the demonstrative pronoun indicates the singular thing and the distance of thing is near as 'this'. Based on the problem, the researcher must be patient to face this problem and find out the alternative way.
In cycle 2, the researcher asked the students to explain clearly the sentence of simple present tense related to the aspects as subject- verb agreement, adverb, and usage; in order that the students could concentrate better and if the students made noise in the implementation of Climbing Grammar Mountain Game, the score would be reduced 10 points. In this cycle, the students concentrated better and got motivated, the students could use the subject - verb agreement, and adverb. It can be seen from the score of the winner, in the first session, that the third group could reach the score 90 and second session, the fourth group could reach the top score. The result of cycle II showed significant improvement. It could also be seen from the result of post test II that the students' mean score was 79 (sufficient) and passed the standard of passing score. In other words, the mean score of post test I improved 15 points into 79 (sufficient) in post test II.

The average score in the pre-test was 42 (poor), and then it improved to 64 (insufficient) in post test I and in post test II became 79 (sufficient). This phenomenon shows that the students' ability in using Simple Present Tense improved significantly. Moreover, the students' achievement in each aspect of Simple Present Tense also improved as can be seen from the graph below.

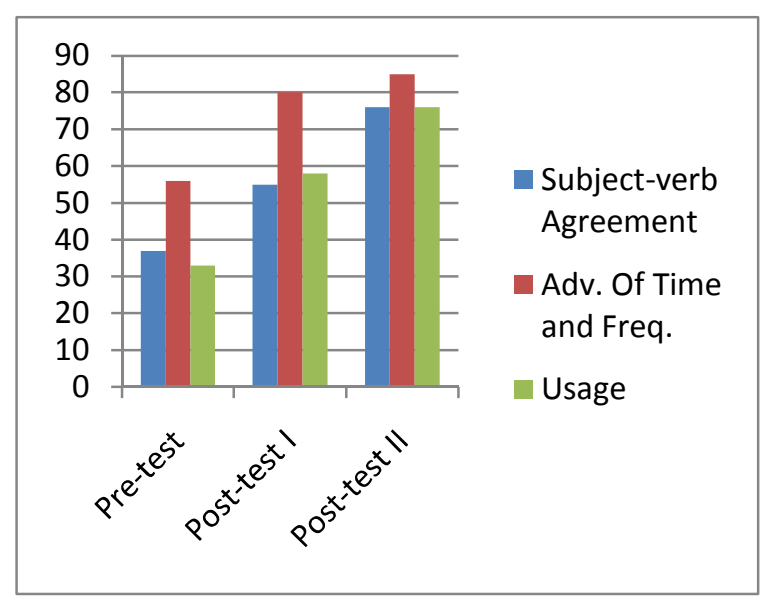

Graph 1. The Students' Mean sScore in Each Aspect of Simple Present Tense 
From the graph, it can be seen that the students' achievement in each aspect of Simple Present Tense improved gradually. First, for the Subject-Verb agreement the students' mean score was 3.7 (poor) in pretest, then it improved to 5.5 (insufficient) in post test I, and finally reached score 7,6 (sufficient) in post test II. Moreover, the students' mean score in using adverbial of time and frequency also improved, that was, from score 5.6 (poor) in pre-test became 8.0 (sufficient) in post test I, and reached score 8.5 (good) in post test II. The same as the other aspect, the students' mean score in using the right usage of Simple Present Tense also satisfactorily improved. The students' mean score on pre-test that was, 33 (poor) improved 25 points in post test I and became 58 (insufficient).

In post test II, it reached score 76 (sufficient). Regarding this, it can be said that the application of Climbing Grammar Mountain Game could improve the ability to use Simple Present Tense in aspects of subject - verb agreement, the use of adverbial time and frequency and the usage of simple present tense through the steps of Climbing Grammar Mountain Game. So, the students participated in learning process and students felt the meaning of studies. In the Climbing Grammar Mountain Game, the students got more practice to use Simple Present Tense specially subject-verb agreement, adverb, and usage. This finding is similar with several studies in EFL classroom such as (Handayani, 2015; Kartina \& Sunaryo, 2014; Safitri, 2015). In the implementation of Climbing Grammar Mountain Game, the teacher could give explanation while they were playing game. But, there was a weakness found in this game, if we only used the steps according to this game, the students would be bored.

Therefore, the implementation of Climbing Grammar Mountain Game were combined with other technique as asking the students to explain the sentence of Simple Present Tense in front of the class and the student was chosen by the teacher in that group at random. Based on the implementation of Climbing Grammar Mountain Game done by students of VIIB of SMPN 1 Luak 50 Kota, they could improve the ability to use Simple Present Tense specially subject-verb agreement, the use of adverbial time and frequency, and the usage of Simple Present Tense. It can be seen from the result of post test II; they reached score 76 (sufficient) and it was in accordance with criteria of this study. Based on the questionnaire and interview in the last session, the students understood Simple Present Tense better since they were asked to make the sentences by themselves. They also said that they had prepared themselves at home to explain their understanding of Simple Present Tense in front of the class orally. So, the Climbing Grammar Mountain Game could make the students motivated and enthusiasm in receiving the material especially Simple Present Tense.

\section{CONCLUSION AND RECOMMENDATION}

Based on the result of the observation and the pre-test done in class VII B of SMPN 150 Kota on the pre observation, it was known that the ability of the students in using Simple Present Tense was low. The students' mean score on the pre test was only 42 which was categorized as poor. This result lead the researcher to do a research by applying Climbing Grammar Mountain Game in the teaching of Simple Present Tense to improve the students' ability in using Simple Present Tense which included two cycles. In the first cycle, this game was able to improve the students' mean score from 42 (poor) into 64 (insufficient). Since the result of post test I had not been satisfactory yet, the researcher then continued to the second cycle in which the game was modified by asking the students to make the sentences used in the game by them and to give explanation in the class discussion.

The result of post test II done in the end of this cycle was satisfactory. The students' mean score improved 37 points from the pre test becoming 79 (sufficient) in the post test II, it was more than criteria of the 
students mean score which were determined in this study and it was significant because it proved that the students enthusiasm to study simple present tense, it mean that the students liked and were not bored again so this was a motivation for them to more concentrate to study simple present tense and they could use it in daily life for communication. Automatically, they will conscious that simple present tense is important in learning English because we use it in daily life in writing and spoken. From this result, it could be concluded that Climbing Grammar Mountain Game could improve the ability of the students in class VII B of SMPN 1 Luak 50 Kota in using Simple Present Tense.

\section{REFERENCES}

Folse, K. S. (2004). Vocabulary myths: Applying second language research to classroom teaching. University of Michigan Press Ann Arbor, MI.

Gunn, C., \& McCallum, A. (2005). Climbing grammar mountain: An interactive learning experience. In English Teaching Forum (Vol. 43, pp. 38-45).

Handayani, S. (2015). Improving the Students' Mastery of Simple Past Tense by Using Climbing Grammar Mountain Game for the Students o Class VIII E of MTS Abadiyah Kuryokalangan Gabus Pati In Academic Year 2014/2015 (A Classroom Action Research). Universitas Muria Kudus. Retrieved from http://eprints.umk.ac.id/5831/.
Hinkel, E. (2002). Teaching grammar in writing classes: Tenses and cohesion. New Perspectives on Grammar Teaching in Second Language Classrooms, 181-198.

Kartina, M., \& Sunaryo, S. (2014). Using climbing grammar mountain game to assess students grammar ability in senior high school. Journal of English Language Teaching, 2(2), 120-127.

Leech, G., \& Svartvik, J. (2013). A communicative grammar of English. Routledge.

Masidjo, I. (1995). Penilaian pencapaian hasil belajar siswa di sekolah. Walter de Gruyter.

Safitri, I. (2015). The Use of Climbing Grammar Mountain to Improve Students'skill in Past Tense. Retrieved from

http://perpus.iainsalatiga.ac.id/docfiles /fulltext/8251826977.pdf.

Saricoban, A., \& Metin, E. (2000). Songs, verse and games for teaching grammar. The Internet TESL Journal, 6(10), 1-7.

Yolageldili, G., \& Arikan, A. (2011). Effectiveness of Using Games in Teaching Grammar to Young Learners. Online Submission, 10(1), 219-229. 